\title{
PARODIA W OPOWIADANIACH TATIANY TOŁSTOJ
}

\author{
PARODY IN TATYANA TOLSTAYA'S STORIES
}

\author{
LILIANA KALITA
}

\begin{abstract}
Tatyana Tolstaya is one of the most accomplished contemporary Russian writers. She represents a postmodernist trend of which parody is a vital part. In her prose one can find parodies of political systems, social groups, romantic ideals, Soviet reality and human behavior. The article analyzes Tolstaya's use of parody in her most popular stories, i.e. Hunting the Wooly Mammoth, Fire and Dust, Night, The Fakir and Okkervil River.
\end{abstract}

Liliana Kalita, Uniwersytet Gdański, Gdańsk - Polska.

Debiut literacki Tatiany Tołstoj miał miejsce przed niemal 30 laty $^{1}$, i od tego czasu pisarka, choć od dekady nie wydała w zasadzie żadnego tomu prozy artystycznej, zajmuje trwałe miejsce $\mathrm{w}$ panteonie rosyjskich pisarzy współczesnych, jako autor „wyrazisty i nietuzinkowy, zdolny kreować swój samodzielny artystyczny świat" 2 . Stylistyka utworów autorki Polowania na mamuta sprawia niemałe kłopoty historykom literatury, wśród których nie milkną spory wokół tego, jaki model pisarstwa reprezentuje Tatiana Tołstoj. Pisarka sytuowana jest zarówno w nurcie prozy realistycznej (Sałajczyk) ${ }^{3}$, jak i postmodernistycznej (Bogdanowa; Lejderman, Lipowiecki) 4 . Krytyka łączy twórczość Tatiany Tołstoj z pisarstwem Bułhakowa i Oleszy, czyli linią tematyczno-stylistyczną literatury rosyjskiej lat 20., która „przyniosła z sobą parodię, błazenadę, święto, ekscentryczność autorskiego «ja»"5. Dbałość autorki o warstwę formalną swoich tekstów, które cechuje

1 W roku 1983 T. Tołstoj zadebiutowała opowiadaniem На золотом крыльце сидели, opublikowanym w czasopiśmie „Аврора”. Był to jeden z najlepszych debiutów literackich roku, a osoba początkującej pisarki od razu zwróciła na siebie uwagę krytyki i czytelników.

2 Opinię Pawła Basińskiego o Tołstoj podaję za źródłem elektronicznym: http://www.lgz. ru/archives/html_arch/lg192004/Tetrad/art11_1.html (27.08.2012).

${ }^{3}$ J. S a $ł$ a j c z y k, Dziesięciolecie przemian. Proza rosyjska lat 1985-1995, Gdańsk 1998.

${ }^{4}$ О. Б о г д а н о в а, Современный митературный процесс (К вопросу о постмодернизме в русской литературе 70-90-х годов ХХ Века), Санкт-Петербург 2001; Н. Л е й д е р м а н, М. Л и п о в е ц к и й, Современная русская литература 1950-1990-е годы: в 2-х томах, Москва 2006.

5 Źródło elektroniczne: http://www.hrono.ru/biograf/bio_t/tolstaja_tn.php (27.08.2012). 
„obrazowość, metaforyczność, barwność - niekiedy nadmierna, nalot lekkości, ironii, gry skryty w najdrobniejszych, celnych detalach i charakterystykach"6, ale również szczególny sposób konstruowania czasu, oparty na cykliczności, łączącej przeszłość z teraźniejszością i przyszłością, zbliża jej twórczość do poezji i nadaje jej wymiar uniwersalny.

Prozie Tatiany Tołstoj, nasyconej odniesieniami intertekstualnymi, sięgającej po instrumenty groteski i wyszukanych stylizacji słownych, nieobce są także cechy parodii, służącej jako narzędzie polemiki ze stereotypami kulturowymi i mentalnymi, a jednocześnie wskazującej na wartości, które są bliskie pisarce. Autorce Petersa właściwe jest oceniające spojrzenie na świat, a zatem motywy parodyjne stały się nieodłącznym elementem świata przedstawionego jej utworów, jako że parodia to forma „satyrycznego rozrachunku z ustalonymi konwencjami literackimi i ukrytymi za nimi stanowiskami ideowo-artystycznymi" 7 . W prozie Tołstoj mamy najczęściej do czynienia z parodią ustroju politycznego, grup społecznych, romantycznych ideałów, sowieckiej rzeczywistości, odwiecznych zachowań ludzkich.

Pisarka chętnie sięga po romantyczne mity, które pozbawia utrwalonej wymowy, pokazując dobrze znane sytuacje w zupełnie innym kontekście. Zwrócili na to uwagę Swietłana i Władimir Piskunowowie, stwierdzając, iż autorka Nocy prowadzi „spór z refleksem sztuki romantycznej w mieszczańskim środowisku, spór z "ersatz-romantyzmem»"8. Takie zabiegi dotyczą chociażby, jak zauważa Helena Goscilo, wzorcowych par kochanków, takich jak Romeo i Julia, Dante i Beatrycze, Abelard i Heloiza9. Doskonałym tego przykładem są opowiadania Охота на мамонта, Поэт и муза, Огонь и пыль.

W pierwszym z wymienionych wyżej opowiadań, zbudowanym na metaforze polowania, parodyjnym zabiegom, tj. przenicowaniu i ośmieszeniu, podlega obiegowe przekonanie, iż to mężczyzna jest stroną aktywną, zdobywającą, w wyniku licznych starań i ponoszonych ofiar, słabą i bezbronną kobietę. Tym razem zdobyczą jest mężczyzna - inżynier Władimir, tytułowy „mamut”, wpadający w sidła drapieżnej Zoji, rejestratorki w szpi-

6 Л. Б а х н о в, Человек со стороны, „Знамя" 1988, № 7, s. 227.

7 Stownik terminów literackich, pod red. J. Sławińskiego, Wrocław-Warszawa-Kraków-Gdańsk 1989, s. 344.

8 С. П и с к у н о в а, В. П и с к у н о в, Уроки зазеркалья, „Октябрь” 1988, № 8, s. 194.

${ }^{9}$ H. G o s c i 1 o, Monsters Monomaniacal, Maritel, and Medical, [w:] Sexuality and the Body in Russian Culture, ed. by Jane T. Costlow, Stephanie Sandler and Judith Vowles, Stanford Univ. Press, 1993, p. 205, [w:] źródło elektroniczne: http://books.google.pl/ books?id=nizLpshQ cIUC\&pg=PA204\&lpg=PA204\&dq=Goscilo,+Monsters,+monomaniacal \&source=bl\&ots=; http://www.O7fF5DOswbsnYBI\&ved=0CDQQ6AEwAQ\#v=onepage\&q $=$ Goscilo $\% 2 \mathrm{C} \% 20$ Monsters $\% 2 \mathrm{C} \% 20$ monomaniacal \&f $=$ false (27.08.2012). 
talu, odczuwającej coraz wyraźniej piętno upływającego czasu i presję społeczną, by „попасть замуж, пока не стукнет двадцать пять"10. Początkowo bohaterka próbuje sposobu zachowania znanego z niewyszukanych romansów lub filmów: udaje roztargnioną lub zamyśloną, wydyma usta, prezentuje miny, które - jej zdaniem - świadczą o bogatym życiu wewnętrznym, w marzeniach projektuje wspólny wyjazd latem na Kaukaz. Stopniowo jednak, gdy coraz bardziej uświadamia sobie, że wybranek nie jest w stanie sprostać jej oczekiwaniom oraz prezentuje prozaiczne podejście do życia, sięga po bardziej radykalne sposoby osaczenia wybranka: kupuje kapcie (symbol mieszczańskiego komfortu), wkłada do portfela Władimira swoje zdjęcie, stawia na parapecie zapaloną lampę, by wskazać wciąż niezdecydowanemu mężczyźnie, gdzie jest jego dom. Proporcjonalnie do czynionych zabiegów wymuszenia na Władimirze oświadczyn rośnie zniecierpliwienie Zoji, jednak rola czarodziejki, którą odgrywa, nie pozwala jej na szczerą rozmowę $\mathrm{z}$ partnerem. Zamiast konfrontacji i zwerbalizowania oczekiwań Zoja ucieka się do nacisków psychologicznych: „враждебно молчала, глядела ему в лоб, посылала телепатические флуиды: женись, женись, женись, женись, женись!" (120). Bohaterce ostatecznie udaje się zdominować Władimira, jednak i to jej nie wystarcza. Finałową scenę można interpretować bądź jako całkowitą kapitulację mężczyzny, osaczonego, niczym zwierzę na polowaniu, nowym stylem życia i zmuszonego do podporządkowania się mu (obraz zaobrączkowanego gołębia), bądź - jeśli podążać śladem metafory i użytej leksyki - jako zabójstwo dokonane przez Zoję na Władimirze (motyw sceny rodzajowej malowanej przez artystę-znajomego Władimira).

Parodyjna wymowa utworu opiera się na elemencie zaskoczenia czytelnika, któremu zamiast kolejnego romantycznego tekstu $\mathrm{z}$ happy endem autorka prezentuje opowieść o dwojgu ludziach, których nic w istocie nie łączy, mających różne wizje życia i upodobania. Relacje bohaterów mają bardzo nacechowany emocjonalnie finał. Romantyczny wątek zostaje zaprezentowany $\mathrm{w}$ zupełnie nowym kontekście, właściwym dla farsy małżeńskiej lub nawet utworu kryminalnego, co pozwala mówić o nasyceniu tekstu ładunkiem parodyjnym. Co więcej, w tej miłosnej historii nie ma w ogóle mowy o miłości ze strony Zoji, bowiem „никогда этот человек ей особенно не нравился [...] он ей всегда был отвратителен" (125). Zoja tylko udaje miłość, imitując zachowania wzorowane na pseudo-romantycznych postawach, $w$ istocie jednak jej celem jest przejęcie pełnej kontroli nad drugim człowiekiem, by z jednej strony napawać się władzą nad nim, z drugiej zaś - udowodnić w pracy, że nie różni się ona od innych kobiet,

10 T. Т о л с т а я, Охота на мамонта, [w:] tejże, Не кысь, Москва 2008, s. 120. O ile nie zaznaczono inaczej, wszystkie cytaty z prozy T. Tołstoj czerpię z tego tomu, podając $\mathrm{w}$ nawiasie numer strony. 
potrafi zrobić akceptowany powszechnie użytek ze swego uroku osobistego. Tatiana Tołstoj wyraźnie kpi z postawy bohaterki, która okazała się osobą przeciętną, skłonną do dominacji nad innymi, a jej ambicje nie sięgają ponad trywialne marzenia o mieszczańskim życiu, polegającym na tym, by

оставшись дома, сидеть в легком и изящном халатике (всюду воланы, производство ГДР) на диване, нога на ногу, чтобы перед глазами - „стенка”, и цветной телевизор (пусть Владимир купит), розовый свет от югославского торшера, и что-нибудь легонькое попивать, и что-нибудь хорошее покуривать (118-119).

Sparodiowanie postawy głównej bohaterki dokonuje się w warstwie narracyjnej, poprzez zestawienie głosu Zoji z głosem narratora, wyraźnie zdystansowanego wobec postawy kobiety, której historię opowiada. Jak zauważa Janina Sałajczykowa, „oba głosy kontrastują ze sobą, co podkreśla ironiczne, a nawet parodyjne zamierzenia autorki"11. Nośnikiem parodii jest również leksyka i składnia, stylizowana na mowę potoczną, właściwa bardziej prozie popularnej niż literaturze dotyczącej romantycznych przeżyć. Widoczne jest to chociażby w opisie Zoji, opartym na „mechanicznym użyciu pewnego chwytu"12, w tym przypadku słownego powtórzenia:

Красивое имя - Зоя, правда? Будто пчелы прожужжали. И сама красива: хороший рост и все такое прочее. Подробности? Пожалуйста, подробности: ноги хорошие, фигура хорошая, кожа хорошая, нос, глаза - все хорошее. Шатенка. Почему не блондинка? Потому что не всем в жизни счастье (115).

Ironia wymierzona jest również w mentalność radzieckiego społeczeństwa, które nie potrafi postrzegać kobiety inaczej niż tylko w związku małżeńskim, małżeństwo zaś traktuje jako przypadkowy dobór osób niezaangażowanych uczuciowo.

Galerię bohaterów prozy Tatiany Tołstoj zaludniają często odmieńcy i dziwacy, których życie pełne jest przypadkowości i absurdu. Ten świadomy chwyt zaczerpnięty jest $\mathrm{z}$ tradycji rosyjskiej literatury i nawiązuje do postaci jurodiwego, którego jedną z funkcji jest parodiowanie świata, uznawanego przez większość za normę. W tym kontekście warto wskazać główne postacie opowiadań Соня oraz Огонь и пьль.

Bohaterka ostatniego z opowiadań to "безумная Светлана по прозвищу Пипка, та, про которую [...] говорили «Да разве Пипка - человек?»" (164), mająca dość swobodny stosunek do życia i relacji z mężczyznami. Wiedzie egzystencję na peryferiach, znika często nie wiadomo gdzie i z kim, a gdy wyłania się z niebytu, opowiada nieprawdopodobne i zmyślone

11 J. S a $\nmid$ a j c z y k, op. cit., s. 109.

12 J. T y n i a n o w, Dostojewski a Gogol. Przyczynek do teorii parodii, tł. A. Pomorski, „Literatura na Świecie” 2012, nr 1-2, s. 280. 
historie na swój temat. Choć niezbyt urodziwa (zamiast zębów ma spalone pieńki dziąseł), swoją ekscentrycznością i fantazją przyciąga mężczyzn, którzy gotowi są spełniać niewiarygodne polecenia Swietki, są one bowiem na tyle niezwykłe, że choć na chwile pozwalają oderwać się od monotonnej radzieckiej rzeczywistości. Swietce przeciwstawiona jest rozsądna i funkcjonująca zgodnie z regułami społecznymi Rimma, z lekceważeniem odnosząca się do swej znajomej, w przekonaniu, że to jej, w nagrodę za uczciwe życie, dostanie się mieszkanie po śmierci lokatora z komunałki - Aszkenaziego. Tymczasem czas mija, Swietka, pozbawiona jakichkolwiek pretensji do świata, otwarta na zmiany, nadal prowadzi życie wolnej i niezależnej, nieobciążonej materialnie kobiety, którą nie targają moralne skrupuły, podczas gdy sytuacja Rimmy to trwanie w oczekiwaniu na spełnienie planów, przy czym bez szybkiej perspektywy ich realizacji:

увидела, что время все плывет, а будущее все не наступает, а Федя не так уж хорош собой, а дети научились на улице нехорошим словам, а старик Ашкенази кашляет да живет, а морщинки уже поползли к глазам и ко рту, а хлам в коридоре все лежит да лежит (172).

Okazuje się zatem, że to szalona Swietka-Pipka potrafiła obrać właściwy styl życia, przewidywalna Rimma zaś tkwi w stagnacji i coraz częściej pojawia się u niej myśl, iż „все кончено, жизнь показала свой пустой лик”.

Ostrze parodii Tołstoj skierowane jest także na tradycyjne wzorce kobiecości, które w jej prozie podlegają zwykle deprecjacji. Wcześniej była już mowa o parodiowaniu typu kobiety zakochanej, marzącej o idealnej miłości. Podobnie rzecz się ma z figurą matki, która w tradycji literackiej jest nosicielką przede wszystkim takich cech jak: poświęcenie, bezgraniczna miłość, ochrona dziecka. W omawianej prozie kobiety - zwykle starsze wiekiem, niekiedy matkujące wnukom w sytuacji braku biologicznej matki, która opuściła swoje dziecko - również nie są pozbawione tych cech, jednak tu są one doprowadzone do skrajności, przez co przeradzają się w swoje własne przeciwieństwo, stając się karykaturą macierzyństwa. Zamiast macierzyńskiego ciepła mamy więc wszechwładne panowanie nad każdą sferą życia podopiecznego, co wywołuje $\mathrm{w}$ nim poczucie duszenia się, ogranicza jego umiejętności społeczne i w efekcie sprawia, że dziecko czuje się nieszczęśliwe.

W opowiadaniu Hous matka głównego bohatera określana jest jako Мамочка i przedstawiona niczym wszechwładne bóstwo, wyznaczające synowi granice jego świata: „Мамочка такая громкая, большая, просторная, а Алексей Петрович маленький [...] Мамочка всевластна. Как она скажет, так и будет" (192). Aleksiej Pietrowicz, jedyny i późny syn 80-letniej bohaterki, to mężczyzna już łysiejący, jednak bez upomnień i wskazówek matki nie jest w stanie wykonać najdrobniejszych czynności wokół 
siebie. W bohaterze niekiedy pojawia się chęć buntu, raz nawet zdobywa się na samowolne wyjście na ulicę, jednak ta próba samodzielności kończy się dramatycznie - Aleksiej zostaje pobity, gdyż zaczepiał kobiety, a w końcu odnaleziony przez matkę, odprowadzony do domu niczym bezradne dziecko, a więc dodatkowo upokorzony: „Мамочка ведет под уздцы Алексея Петровича в теплую нору, в мягкое гнездо, под белое крыло" (200). Lęk przed światem i życiem, doświadczany przez bohatera, to w dużym stopniu efekt toksycznej miłości matki, nie potrafiącej zadbać we właściwym czasie o to, by syn nauczył się choć w minimalnym stopniu troszczyć o siebie.

Narracja prowadzona jest z punktu widzenia Aleksieja Pietrowicza, imitującego infantylny styl, którym do syna przemawia jego matka, co zważywszy na fakt, iż mężczyzna ma lat ok. 40, staje się znakomitym narzędziem parodii, ujawnia bowiem zasięg dominacji kobiety.

Skutki babcinego wychowania, powodujące izolację społeczną bohatera, brak woli i umiejętności dokonywania wyborów znajdujemy również $\mathrm{w}$ opowiadaniu Петерс, w którym poznajemy tytułowego bohatera najpierw jako chłopca, tresowanego według zasad kindersztuby, a potem mamy okazję przekonać się, jak ten styl wychowawczy sprawdza się w życiu dorosłego już mężczyzny. Tymi rozważaniami pisarka wpisuje się w postmodernistyczny dyskurs nad kwestią męskości we współczesnym świecie. Jej symbolem staje się kurczak-brojler, do którego porównany zostaje bohater: „холодный куриный юноша, не познавший ни любви, ни воли, - ни зеленой муравы, ни веселого глаза подруги" (273). Ten parodyjny obraz mężczyzny, nieznającego realnego świata, niepotrafiącego nawiązać kontaktu z kobietami, żyjącego marzeniami, z których ani jednego nie jest $\mathrm{w}$ stanie zrealizować, wyśmiewany i odrzucany przez innych, jest świadectwem rozdźwięku między zasadami wpojonymi bohaterowi przez babcię a regułami rzeczywistości, w której dorosłemu Petersowi przyszło żyć. Finałowa scena przynosi wprawdzie nadzieję na to, iż Peters pokonał swoją nieśmiałość i gotowy jest nadrobić stracony czas, jednak staje się to już chyba trochę zbyt późno - bohater jest już starym człowiekiem, a zapowiadane zmiany funkcjonują na poziomie potencjalnym, a nie dokonanym, co pozwala nam traktować je sceptycznie.

Parodyjne ujęcie obrazu mężczyzny, postrzegającego siebie jako naturę romantyczną, utrudniającą funkcjonowanie we współczesnej rzeczywistości rosyjskiej, dostrzec można również w utworze Чистый ^ист. Mamy tu do czynienia z bohaterem, którego, niczym u romantyków, głównym źródlem jestestwa jest dusza. Ignatiewa zewsząd otacza choroba - chory jest świat, w którym przyszło mu żyć, choroba zawładnęła przestrzenią jego domu: z powodu poważnej dolegliwości syna żona Ignatiewa, na którą spadł przeważający ciężar opieki, jest osobą wyniszczoną i wiecznie zmę- 
czoną, sam bohater również cierpi wewnętrznie, widząc zmagania bliskich. Delikatną, pełną współczucia i zrozumienia duszę Ignatiewa odwiedza co noc niezwykły gość, którego natura wywodzi się z romantyzmu: „каждую ночь к Игнатьеву приходила тоска. Тяжелая, смутная, с опущенной головой..."13, w efekcie czego problemy bohatera zaczynają go przerastać, a nie wiedząc, jak je rozwiązać, Ignatiew w rzeczywistości nie robi nic poza analizowaniem własnej psychiki. Osobowość bohatera staje się rozchwiana, a jego wyobraźnia podsuwa mu w snach koszmarne obrazy bliskich, powodując $\mathrm{w}$ nim wzrost poziomu lęku. Symbolem duszy staje się męczące bohatera "живое", odpowiedzialne, zdaniem Ignatiewa, za jego melancholijne stany, o którym tak opowie on swojemu przyjacielowi:

- Я не понимаю, - говорил друг, ну что ты выкобениваешься? У всех примерно такие обстоятельства, в чем дело? Живем же как-то.

- Ты пойми: вот тут, - Игнатьев показывал на грудь, - живое, живое, оно болит!

- Ну и дурак, - друг чистил зуб спичкой. - Потому и болит, что живое. А ты как хотел ${ }^{14}$.

Gdy świadomość istnienia duszy, która ogranicza możliwości bohatera korzystania z uroków świata bez wyrzutów sumienia, staje się już zbyt dojmująca, Ignatiew decyduje się dobrowolnie na operację, która usunie w nim „живое”, w zamian za co rozpocznie się u niego „жизнь [...] Жизнь! Здоровая, полноценная жизнь, а не куриное копание"15. Rezultaty zabiegu okazują się jednak głęboko tragiczne - Ignatiew pozbawiony duszy to człowiek martwy, odarty z żywej wyobraźni, moralny degenerat, którego los żony niewiele już obchodzi i który planuje umieścić syna, nazywanego od czasu operacji nie inaczej jak tylko „недоноском", w domu opieki. Nowy Ignatiew jest $w$ istocie bez-duszny, to ograniczony, tępy, egocentryczny mężczyzna, którego biografia zaczyna kształtować się na nowo, wchodzi on w życie z "czystą kartą", jednak czytelnik już wie, że zapisana ona zostanie raczej czynami niechlubnymi, i świadomość ta wywołuje pesymistyczne odczucia.

W wielu opowiadaniach sięga Tatiana Tołstoj po chwyt gry realizowany na różnych poziomach: tematyczno-ideowym, psychologicznym, stylistycznym. Zabieg taki obecny jest m.in. w takich tekstach jak Факир, Соня, Сомнамбула $b$ тумане, Река Оккервиль, gdzie przedstawiony jest kontrast między sferą duchową bohaterów, ich często niezrealizowanymi marzeniami, a realnym życiem, opartym - z własnego wyboru - na grze i fałszywej egzystencji.

\footnotetext{
13 Т. Т о л с т а я, Чистый ^ист, [w:] tejże, Река Оккервиль, Москва 1999, s. 154.

14 Ibidem, s. 158.

15 Ibidem, s. 162.
} 
Bohater utworu Фakup to postać niczym z opowieści Tysiaca i jednej nocy. Kolekcjoner niezwykłych, pięknych drobiazgów raz w miesiącu zaprasza do siebie Galę i Jurę, mieszkańców peryferyjnego osiedla, by pokazać nowy nabytek, ugościć wyszukaną potrawą, przedstawić specjalnie zaproszonego gościa odznaczającego się rzadkim talentem i opowiedzieć kolejną fascynującą historię ze swojego bogatego w doświadczenia życia. Zachowanie Filina, otaczająca go atmosfera przytulności i egzotyki silnie wpływa szczególnie na Galinę (Jura jest bardziej sceptyczny i nie poddaje się tak łatwo urokowi znajomego), traktującą wizyty w domu znajomego jak szansę na krótkotrwałe choćby oderwanie się od szarej, pełnej zmagań i trosk, codzienności (podróż z mieszkania, usytuowanego przy obwodnicy, do domu Filina, znajdującego się w centrum Moskwy, nabiera symbolicznych cech awansu społecznego i kulturowego). Gala postrzega życie tytułowego bohatera jako pełne głębokich duchowych przeżyć, wypełnione pasją i ciekawymi doznaniami. Ostatecznie idealna egzystencja Fakira okazuje się być starannie przez niego wykreowana, bowiem ani mieszkanie, ani znajdujące się w nim sprzęty nie należą do bohatera, jego opowieści są również tylko wymysłem, by zrobić na otoczeniu wrażenie i samemu przez to poczuć się wyjątkowym ${ }^{16}$. Bohater doskonale wyczuł potrzeby inteligencji radzieckiej epoki Breżniewa, której marzenie o odrobinie komfortu materialnego nie mogło być zrealizowane, i na stwarzaniu wrażenia o możliwości jego zaspokojenia oparł swoje oszustwo. Filin także chciał żyć w bajkowym świecie, jednak nie podejmował ryzyka realizacji tych pragnień, choć, trzeba przyznać, został wierny przyjętej przez siebie strategii zachowania. Nieco więcej odwagi wykazali w tej kwestii Gala i Jura, czyniąc starania o zamianę swego mieszkania (aluzja do utworu Trifonowa Zamiana wydaje się być znakiem czasu, którego dotyczy opowiadanie) czy zapraszając do siebie poznane u Filina osoby, jednak te działania wynikały z czysto materialnych i snobistycznych pobudek. Gala z łatwością dała się oczarować osobowości fakira i uległa pokusie otaczania się zgromadzonymi w mieszkaniu przedmiotami jedynie dla samego poczucia ich posiadania. Planowała nawet opuszczenie męża i związanie się z Filinem. W efekcie bohaterka ze zwyczajnej, nawet sympatycznej w swych słabościach, kobiety, mającej te same troski i radości co większość jej rodaczek, zmienia się w osobę, która na chłodno kalkuluje, czy opłaci się jej zaprosić kolejnego gościa, oraz surowo ocenia właścicielkę upatrzonego mieszkania, gdy ta rozmyśliła się co do zamiany. Ten właśnie kierunek zmian dokonujący się w Gali jest piętnowany przez autorkę. Tatiana Tołstoj, jak można wnioskować z powyższego opowiadania, przestrzega przed chodzeniem w życiu na skróty, przed

${ }^{16}$ N. Lejderman i M. Lipowiecki zwrócili uwagę, iż bajki opowiadane przez Filina to parodia elementów sowieckiej kultury masowej. Por.: Н. Л е й д е р м а н, М. Л и п о в е ц к и й, op. cit., t. 2, s. 469. 
przedkładaniem wartości materialnych nad duchowe, stoi na stanowisku, że należy cenić i dbać o to, co już realnie posiadamy, nawet jeżeli świat i otoczenie kuszą obietnicą lepszej egzystencji.

Ironicznie potraktowany jest przez pisarkę także bohater opowiadania Река Оккервиль. Zakochany w głosie Wiery Wasiliewny samotnik Simeonow żyje w przekonaniu, że jego ulubiona śpiewaczka już nie żyje i przetrwała jedynie jego miłość i pamięć o niej. Okazuje się jednak, iż idealizowana przez bohatera kobieta nadal mieszka w Petersburgu, więc bohater decyduje się ją odwiedzić. Ku swojemu zaskoczeniu pod wskazanym adresem zastaje nie delikatną istotę, wspominającą z rozrzewnieniem chwile dawnej sławy, ale kobietę potężnej postury, opowiadającą żarty, z apetytem pochłaniającą jedzenie i z zadowoleniem przyjmującą adoracje bynajmniej nie elitarnych gości. Szok bohatera pogłębia się, gdy mieszkająca w domu bez łazienki Wiera Wasiliewna przyjeżdża do Simeonowa wykąpać się i bohater musi wysłuchiwać naturalistycznych odgłosów kąpieli, a potem obserwuje ślady tej kąpieli na wannie. Bohater nie jest $\mathrm{w}$ stanie znieść prawdy, iż wielbiona artystka jest takim samym człowiekiem jak inni, i w geście obrony wybiera drogę ucieczki od faktów w ułudę, przekonuje samego siebie, że Wiera Wasiliewna umarła.

Rzeczywistość rosyjska czasów po pieriestrojce, wszechobecna komercjalizacja, świat „nowych Rosjan” stały się tematem humorystycznego opowiadania Ложка для картоф. Przedstawia ono historię wizyty bohaterki $\mathrm{w}$ sklepie z artykułami gospodarstwa domowego. Groteskowa jest już sama nazwa sklepu: „магазин назывался «Фея домашнего очага» - нечто исключительно языческое и сакральное, возможно, предполагающее даже ритуальное обнажение" (214). Protagonistce przyszło się zmierzyć z koniecznością zostawienia torby w szafce, podejrzliwością obsługi, podążającej za nią krok w krok, a wreszcie z cenami sprzedawanych tam towarów: „Сервиз стоил 5485200 рублей ровно. Стало быть, 914200 на каждого. Почти миллион старыми. Сто сорок семь долларов" (215). Świadomość wartości przedmiotu sprawiła, iż bohaterka zaczęła zastanawiać się, komu ze swoich znajomych, bez narażenia na rozbicie filiżanek, mogłaby podać $\mathrm{w}$ nim herbatę. Konsekwencją przyjętego rozumowania było m.in. dojście do wniosku, iż należy zerwać kontakty z przyjaciółmi. Szczytem cenowego absurdu okazała się tytułowa łyżka do ziemniaków za dwa miliony osiemset czterdzieści tysięcy czterysta rubli. Można by odnieść wrażenie, że bohaterka trafiła do wyjątkowo luksusowego salonu, jednak jego organizacja (musiała wyjść na zewnątrz sklepu i obejść go, by wrócić po torebkę) oraz zachowanie pracowników, traktujących klientkę $\mathrm{w}$ obcesowy sposób, pozwalają nam sądzić, iż był to sklep, jakich wiele. W opowiadaniu tym pisarka jako narzędzie parodii ośmieszającej sztuczne windowanie cen zastosowała tradycyjny chwyt fabularny, znany chociażby 
z prozy Gogola, zgodnie z którym to przedmiot jest ważniejszy od osób go użytkujących. Podobnie jak Zoszczenko, w swych satyrycznych tekstach pokazała również, iż ze zmianą polityczno-gospodarczą nie idzie w parze zmiana mentalności ludzi, bo choć czasy są nowe, Rosjanie nadal wykorzystują stanowisko, by pokazać swą wyższość nad innymi, a typ pouczającego wszystkich dozorcy okazuje się niezwykle trwały. Zdaniem Bogdana Dziemidoka "parodiowanie łączy w sobie naśladowanie oryginału z uwydatnieniem jego charakterystycznych cech, z wyolbrzymieniem ich niekiedy do granic absurdu"17. I właśnie $\mathrm{z}$ takim zamierzeniem stylistycznym mamy tu do czynienia. Refleksja bohaterki wynikająca z zaistniałej sytuacji ma zarówno humorystyczną, jak i gorzką wymowę - przynosi bowiem ocenę współczesnej Rosji, w której na silne doznania liczyć można jedynie w sklepie:

Как радостно сердцу! Где еще, когда еще - подумать только! - можно за каких-то там полчаса в какой-то там посудной лавке - пережить весь основной набор эмоций, не всегда-то в полной мере и выпадающий на долю человеку в течение жизни? Страх, глупость, тщеславие, искупление, унижение, жадность, предательство, снобизм, паранойя - мои, не чьи-нибудь (218).

Tatiana Tołstoj uchodzi za autorkę świadomie korzystającą z formy językowej, swobodnie poruszającą się w obszarze różnych stylistyk i potrafiącą, zgodnie z postmodernistyczną regułą, tworzyć specyficzny klimat swych tekstów. Nie jest więc chyba przypadkiem, że i sam język rosyjski staje się tematem jej utworów. Tak się dzieje np. w opowiadaniu Ha ^unoвой ноге, w którym pisarka rozpatruje historię języka ojczystego przez pryzmat pojawiania się $\mathrm{w}$ nim obcych wyrażeń i tendencji do upraszczania leksyki. Zmiany takie charakterystyczne są dla przełomowych momentów w dziejach narodu, do których Tatiana Tołstoj zalicza czasy Piotra I, rewolucję październikową i pieriestrojkę. $Z$ dużą dozą ironii opisuje ona proces ujednolicania języka, obserwowany zanik kultury językowej (będący świadectwem upadku kultury w ogóle), przejawiający się m.in. w tym, iż Rosjanie przestają wykorzystywać synonimiczne określenia, zastępując je jednym modnym $\mathrm{w}$ danym czasie wyrażeniem, np. клёвыu. Pisarka dla uzmysłowienia konsekwencji takiego faktu trawestuje lirykę Puszkina, zamieniając w niej wyszukane epitety modnymi współcześnie przymiotnikami, co daje doskonały efekt parodyjny, przy czym zabieg ten nie ośmiesza romantycznego poety, znanego skądinąd z zamiłowania do parodii, lecz obecne czasy $\mathrm{i}$ istniejące $\mathrm{w}$ nim zjawiska. Inne rozważania dotyczą m.in. zastępowania spójnika „i" słowem „end”, co wielokrotnie prowadzi do absurdu (Серый волк end Красная Шапочка), oraz budowania wypowiedzi za pomocą rów-

17 B. D z i e m i d o k, O komizmie, Warszawa 1967, s. 61. 
noważników zdań, czego przykładem może być fragment poniższej rozmowy w salonie piękności, między fryzjerką a klientką, która niedawno wróciła z wakacji:

П. (стрижет): Ну как Кипр?

Д. (оживляясь): О, Кипр клев! Пляж, бар - сплошь плюш; сок, джин, дринк. Как ночь - муж в душ, дочь - прочь, тут грек Макс - тук-тук! - враз секс, кекс, бакс, крекс, фекс, пеке. Вот так-с! (223-224).

Opowiadanie Ha ıиnовой ноге to satyra na mentalność Rosjan, świadczącą o ich intelektualnej degradacji, przejawiającą się w sposobie użycia przez nich języka, na proces szerzenia się kulturowego prostactwa i rozpad więzi społecznych, sprowadzonych na poziomie werbalnym do wymiany okaleczonych dźwięków, a nie słów.

W prozie Tatiany Tołstoj elementy parodyjne wykorzystywane są często jako świadectwo rozdźwięku między kulturą wysoką a materialną sferą egzystencji człowieka, jako narzędzie pokazania absurdu rzeczywistości, jako gra różnorakimi konwencjami gatunkowymi i kategoriami literackimi. Pisarka chętnie sięga po instrumenty parodii, by ośmieszać kody kulturowe, wynaturzoną psychikę ludzką czy życie w Rosji współczesnej, przekonana zapewne o prawdziwości tezy, iż "parodia [...] nie zna nienaruszalnych autorytetów"18. Przy czym cechą parodii właściwą twórczości Tołstoj jest to, iż elementy parodyjne nie przejawiają się w jej tekstach wprost, pisarka bowiem adresuje swe teksty do wyrobionego czytelnika, potrafiącego odbierać jej prozę na różnych, a szczególnie tych głębszych, poziomach.

W roku 2000 Tatiana Tołstoj wydała jedyną swoja powieść - utwór Kысъ, utrzymany $\mathrm{w}$ gatunku antyutopii, a więc programowo nawiązujący do idei idealnego państwa i ceny, jaką się za nie płaci. Pisarka odniosła się w nim do kondycji człowieka niemającego oparcia w kulturze i do znaczenia samej kultury, podejmując $w$ ten sposób po raz kolejny temat, który jest typowy dla jej twórczości. Podobnie jak w opowiadaniach, w utworze tym znalazły zastosowanie na szeroką skalę różnorakie elementy parodii i groteski, jednak ich omówienie wykracza poza ramy niniejszego artykułu.

18 W. N o w i k o w, Parodia i śmiech parodiowy, tł. E. Przechodzki, „Akcent” 1991, nr 2-3, s. 137. 
